\title{
Penyelesaian Perkara Pemutusan Hubungan Kerja Di Pengadilan Hubungan Industrial Kota Palembang
}

\author{
Ayu Puspasari ${ }^{1}$, Wasitoh Meirani ${ }^{2}$, Muhammad Erwin $^{3}$, Suroso $^{4}$ \\ ${ }^{1}$ Politeknik Negeri Sriwijaya, Jl. Srijaya Negara, Bukit Lama, Bukit Besar, Palembang, 30139 \\ E-mail: Ayupuspasari@polsri.ac.id \\ ${ }^{2}$ Politeknik Negeri Sriwijaya, Jl. Srijaya Negara, Bukit Lama, Bukit Besar, Palembang, 30139 \\ E-mail: Wasitohmeirani@polsri.ac.id \\ ${ }^{3}$ Politeknik Negeri Sriwijaya, Jl. Srijaya Negara, Bukit Lama, Bukit Besar, Palembang, 30139 \\ E-mail: Muhammaderwin@polsri.ac.id \\ ${ }^{4}$ Politeknik Negeri Sriwijaya, Jl. Srijaya Negara, Bukit Lama, Bukit Besar, Palembang, 30139 \\ E-mail:Suroso@polsri.ac.id
}

\begin{abstract}
This study aims to explain and analyze the settlement of disputes in cases of termination of employment at the Palembang Industrial Relations Court. The research method used in this research is a type of empirical legal research (juridical empirical) that sees law as facts. The results showed that the incidence of termination of employment in Palembang City was caused by several factors, but the most dominant was that qualified workers/laborers resigned. The process of resolving a case of termination of employment at the Palembang Industrial Relations Court can be carried out using a quick program and an ordinary event. The two events, which are most often used to resolve cases of termination of employment at the Palembang City Industrial Relations Court, are normal. The obstacle related to the judges of the Palembang City Industrial Relations Court in resolving cases of termination of employment is that the parties do not agree on severance pay. The author suggests that the parties in a case state cooperative, not concerned with their respective egos related to severance pay so that the settlement of the case for termination of employment at the Industrial Relations Court can run smoothly. Besides, Industrial Relations Court judges also need to explain if the party does not agree on severance pay.
\end{abstract}

Keywords_-: Settlement; Termination of Employment; Industrial Relations Court.

\section{PENDAHULUAN}

\section{A. Latar Belakang}

Hubungan antara pekerja/ buruh dan pemberi kerja/ pengusaha dapat berakhir karena ada pemutusan hubungan kerja atau yang lebih dikenal dengan singkatan "PHK". Undang-Undang Republik Indonesia Nomor 13 Tahun 2003 tentang Ketenagakerjaan (UU No. 13 Tahun 2003) telah menentukan mengenai PHK yang harus dipenuhi oleh pemberi kerja/pengusaha sebagaimana dicantumkan dalam Bab XII, mulai dari Pasal 150 sampai dengan Pasal 173. Masalah PHK di dunia ketenagakerjaan, akhir-akhir ini menjadi pembahasan yang serius karena jumlah pekerja/ buruh yang di PHK mengalami kenaikan yang cukup signifikan di Indonesia.

Pada tahun 2019, PHK secara besar-besaran terjadi mulai dari perusahaan bidang perbankan hingga bidang otomotif. Beberapa perusahaan yang melakukan PHK besar-besaran pada tahun 2019, yaitu: ${ }^{1}$

1. PT. Hero Supermarket Tbk. (HERO) melakukan penutupan 26 gerai dan mem-PHK 536 orang karyawannya;

2. PT. Krakatau Steel Tbk. (KRAS) melakukan PHK terhadap 1.300 orang karyawannya;

3. Nissan Motor melakukan PHK terhadap karyawannya sebanyak 830 orang; dan

4. Bukalapak (perusahaan marketplace) melakukan PHK terhadap 150 orang karyawannya.

Dengan demikian, telah terjadi PHK secara besar-besaran yang dilakukan oleh perusahaan di Indonesia. Data dari Badan Pusat Statistik (BPS) menunjukkan bahwa pada bulan Agustus 2019 jumlah pekerja formal yang di PHK mengalami kenaikan dibandingkan dari tahun sebelumnya (2018). Pada tahun 2019 (bulan Agustus) jumlah pekerja yang di PHK adalah 44,28 juta, sedangkan pada tahun 2013 sebanyak 43,16 juta orang. Dari jumlah itu, pekerja dengan status karyawan masih mendominasi, yaitu sebanyak 40,83 juta orang pada bulan Agustus 2019 lebih banyak dibandingkan dengan bulan yang sama pada tahun $2018 .^{2}$

Keadaan tersebut merupakan hal yang sangat memprihatinkan karena ribuan orang harus kehilangan pekerjaan dan konsekuensinya keadaan ekonomi keluarganya melemah. Pada saat memperingati hari buruh (Mayday) tanggal 1 Mei 2019,

\footnotetext{
1 Dewi Aminatuz Zuhriah, Ketika Momok PHK Mengintai Dunia Ketenagakerjaan Indonesia, Terdapat dalam https://ekonomi.bisnis.com/read/20191209/12/1179407/ketika-momok-phk-mengintai-dunia-ketenagakerjaan-indonesia, (akses 4 Desember 2019). 
masalah PHK menjadi salah satu bagian dari tuntutan para pekerja/ buruh yang tergabung dalam Asosiasi Serikat Pekerja Indonesia (ASPEK Indonesia). Di dalam aksinya tersebut, buruh menuntut pemerintah agar menghentikan PHK secara massal di berbagai sektor, seperti retail, telekomunikasi, perbankan, kesehatan, media, dan sektor lain. ${ }^{3}$

UU No. 13 Tahun 2013 meskipun telah mengatur tentang PHK yang harus dipenuhi oleh pemberi kerja/ pengusaha, namun dalam praktik masih terjadi perselisihan antara pekerja/ buruh dengan pemberi kerja/ pengusaha. Perselisihan terkait PHK adalah hal wajar sebagai salat satu perselisihan yang terjadi di kehidupan masyarakat. Hal itu selaras dengan pendapat Asyadi dalam Asikin, bahwa:

"Secara sosilogis, perselisihan dapat terjadi di mana-nama, di lingkungan rumah tangga, sekolah, pasar, terminal, perusahaan, kantor, dan sebagainya. Secara psikologis, perselisihan merupakan luapan emosi yang mempengaruhi hubungan seseorang dengan orang lain. Masalah perselisihan merupakan hal yang lumrah karena telah menjadi kodrat manusia itu sendiri"4.

Secara yuridis, perselisihan yang terjadi terkait dengan PHK merupakan salah satu jenis perselisihan hubungan industrial. Hal ini dapat dilihat dalam ketentuan mengenai batasan perselisihan hubungan industrial yang dicantumkan dalam Pasal 1 angka 2 UU No. 13 Tahun 2003 dan Pasal 1 angka 1 Undang-Undang Republik Indonesia Nomor 2 Tahun 2004 tentang Penyelesaian Perselisihan Hubungan Industrial (disingkat UU No. 2 Tahun 2004). UU No. 13 Tahun 2003 telah menentukan bahwa salah satu cara yang dapat digunakan untuk menyelesaikan perselisihan hubungan industrial (termasuk PHK) adalah secara litigasi. Penyelesaian secara litigasi ini baru dapat dilakukan setelah diselesaikan dengan cara non-litigasi. ${ }^{5}$ Lembaga yang menyelesaian perkara perselisihan hubungan industrial secara litigasi disebut Pengadilan Hubungan Industrial. ${ }^{6}$

UU No. 13 Tahun 2003 jo. UU No. 4 Tahun 2004 meskipun telah mewajibkan untuk menyelesaikan perkara perselisihan hubungan industrial secara non-litigasi, tetapi faktanya masih banyak perkara yang diselesaikan secara litigasi melalui Pengadilan Hubungan Industrial. Di kota Palembang misalnya, perkara perselisihan hubungan industrial di Pengadilan Hubungan Industrial mengalami kenaikan dari tahun sebelumnya. Pada tahun 2019, jumlah perselisihan hubungan industrial di Pengadilan Hubungan Industrial adalah 166 perkara. Jumlah itu lebih tinggi dibanding tahun sebelumnya (2018) yang hanya 71 perkara. Perkara perselisihan hubungan industrial tahun 2019 di Pengadilan Hubungan Industrial Kota Palembang didominasi oleh perkara PHK, baik yang dilakukan secara sepihak maupun massal. ${ }^{7}$

Ada beberapa putusan Pengadilan Hubungan Industrial Palembang terkait dengan penyelesaian perkara PHK, diantaranya adalah putusan nomor 32/Pdt.Sus-PHI/2019/PN.Plg. Majelis hakim dalam putusan itu mengabulkan gugatan penggugat (Hermawan) yang telah di PHK oleh PT. Multi Bangunan Abadi (PT. MBA) serta menghukum tergugat (PT. MBA) agar membayar pesangon dan uang penghargaan sebesar Rp. 106.737.194,- (Seratus Enam Juta Tujuh Ratus Tiga Puluh Tujuh Ribu Seratus Sembilan Puluh Empat Rupiah). Putusan lainnya dapat dilihat pada putusan nomor 31/Pdt.Sus-PHI/2019/PN.Plg dan putusan nomor 62/Pdt.Sus-PHI/2019/PN.Plg. Putusan pertama menyatakan gugatan pengugat (Adi Jumadi) yang di PHK oleh PT. Maju Mix Bersama Abadi (PT. MMBA) sebagai tergugat, tidak dapat diterima. Sementara putusan yang kedua mengabulkan gugatan penggugat (Joko Purnomo) untuk sebagian dan menghukum PT. Eka Jaya Multi Perkasa (PT. EJMP) sebagai tergugat untuk membayar kekurangan bayar upah lembur kepada penggugat sebesar Rp. 102.174.035,-(Seratus Dua Juta Seratus Tujuh Puluh Empat Tiga Puluh Lima Rupiah).

Bertolak dari keadaan tersebut di atas, maka penulis tertarik untuk meneliti lebih lanjut tentang upaya Pengadilan Hubungan Industrial kota Palembang dalam menyelesaikan perkara perselisihan PHKyang dilakukan oleh pemberi kerja/perusahaan. Penelitian ini kemudian penulis tuangkan dalam bentuk karya ilmiah berjudul: "Penyelesaian Perkara Pemutusan Hubungan Kerja Di Pengadilan Hubungan Industrial Kota Palembang”.

\section{B. Rumusan Masalah}

Berdasarkan uraian latar belakang di atas, maka rumusan masalah dalam penelitian ini, yaitu:

1. Faktor-faktor apakah yang melatarbelakangi terjadinya pemutusan hubungan kerja di Kota Palembang?.

2. Bagaimana proses penyelesaian perkara pemutusan hubungan kerja di Pengadilan Hubungan Industrial Kota Palembang?.

3. Kendala apa saja yang dihadapi oleh hakim Pengadilan Hubungan Industrial Kota Palembang dalam menyelesaikan perkara pemutusan hubungan kerja?

\section{Tujuan Penelitian}

Penelitian ini dilakukan dengan tujuan:

1. Untuk mengetahui, menjelaskan, dan menganalisis faktor-faktor yang melatarbelakangi terjadinya pemutusan hubungan kerja di Kota Palembang.

\footnotetext{
${ }^{3}$ CNN Indonesia, May Day, Pekerja Ajukan Tujuh Tuntutan Ke Pemerintah, Terdapat dalam https://www.cnnindonesia.com/ekonomi/20190430145434-92390870/may-day-pekerja-ajukan-tujuh-tuntutan-ke-pemerintah, (akses 5 Desember 2019).

${ }^{4}$ Dahlia \& Aghata Jumiati. (2011). Penyelesaian Perselisihan Hubungan Industrial Berdasarkan UU No. UU Tahun 2004. Wacana Hukum, Vol. IX No. 2, Oktober, hal. 39.

${ }^{5}$ Pasal 136 UU No. 13 Tahun 2003.

${ }^{6}$ Pasal 3 s/d Pasal 5 UU No. 4 Tahun 2004

${ }^{7}$ Daftar Perkara Pengadilan Hubungan Industrial Kota Palembang, Terdapat dalam http://sipp.pn-palembang.go.id/list_perkara, (akses 5 Desember 2019).
} 
2. Untuk mengetahui, menjelaskan, dan menganalisis proses penyelesaian perkara perselisihan pemutusan hubungan kerja di Pengadilan Hubungan Industrial Kota Palembang.

3. Untuk mengetahui, menjelaskan, dan menganalisis kendala-kendala yang dihadapi oleh hakim Pengadilan Hubungan Industrial Kota Palembang dalam menyelesaikan perkara perselisihan pemutusan hubungan kerja.

\section{METODE PENELITIAN}

Penelitian ini termasuk ke dalam jenis penelitian hukum empiris atau yuridis empiris karena hukum dilihat dalam kenyataannya. ${ }^{8}$ Sesuai dengan permasalahannya, maka lokasi penelitian ini dilakukan di Pengadilan Hubungan Industrial Kota Palembang. Populasi merupakan objek penelitian secara keseluruhan, yang dalam hal ini adalah seluruh perkara pemutusan hubungan kerja yang diselesaikan di Pengadilan Hubungan Industrial Kota Palembang pada tahun 2019. Dari populasi tersebut, yang mendai sample dalam penelitian ini hanya sebanyak 10 perkara pemutusan hubungan kerja yang diselesaikan oleh Pengadilan Hubungan Industrial Kota Palembang tahun 2019.

Data yang digunakan dalam penelitian ini adalah data primer, yaitu data yang diperoleh langsung dari masyarakat, yang dalam hal ini hakim atau pejabat Pengadilan Hubungan Indusrtial Kota Palembang. Di samping itu, penelitian ini juga menggunakan data sekunder, yaitu data yang diperoleh dari bahan-bahan kepustakaan. Data sekunder ini bersumber dari bahan hukum primer, sekunder, dan tersier. Data-data yang digunakan dalam penelitian ini dikumpulkan dengan teknik studi kepustakaan (dokumentasi) dan wawancara. Data penelitian yang telah terkumpul, kemudian dianalisis dengan teknik content analisys (analisis isi). Setelah dianalis, selanjutnya ditarik kesimpulan dengan logika berfikir induktif, yaitu penarikan kesimpulan yang dimulai dari hal-hal yang bersifat khusus yang kemudian diterapkan kepada hal-hal yang bersifat umum.

\section{III.ANALISIS DAN PEMBAHASAN}

\section{A. Faktor-faktor yang Melatarbelakangi Terjadinya Pemutusan Hubungan Kerja Di Kota Palembang}

Menurut Asri Wijayanti, pemutusan hubungan kerja (PHK) merupakan suatu keadaan dimana buruh berhenti bekerja dari majikan. ${ }^{9}$ Tulus sebagaimana dikutip oleh Brankas Everest menyatakan bahwa PHK (separation) adalah mengembalikan karyawan ke masyarakat. ${ }^{10}$ Hasibuan berpendapat bahwa PHK adalah pemberhentian seseorang karyawan dengan suatu organisasi (perusahaan). ${ }^{11} \mathrm{Jadi}$, PHK merupakan tindakan pengusaha yang berupa memberhentikan atau menghentikan pekerja/ buruh untuk bekerja di dalam perusahannya. Dengan pemberhentian tersebut, maka pekerja/buruh kembali lagi ke masyarakat.

Secara yuridis, masalah PHK ini diatur dalam UU No. 13 Tahun 2003 tentang Ketenagakerjaan. PHK menurut undangundang tersebut adalah pengakhiran hubungan kerja karena suatu hal tertentu yang berakibat pada berakhirnya hak dan kewajiban antara buruh/pekerja dan pengusaha. ${ }^{12}$ Dengan demikian, PHK oleh pengusaha didasarkan oleh alasan-alasan tertentu. Akibat dari terjadinya PHK adalah berakhirnya hubungan antara buruh/pekerja dan pengusaha yang berupa hak dan kewajiban. Artinya, pekerja/buruh dan pengusaha tidak lagi mempunyai hak dan kewajiban karena hubungannya terlah berakhir.

PHK yang terjadi kemungkinan besar dapat menimbulkan permasalahan antara pekerja/buruh dengan pengusaha. Permasalahan PHK ini termasuk ke dalam perselisihan hubungan industrial. UU No. 2 Tahun 2004 tentang Penyelesaian Perselisihan Hubungan Industrial telah menentukan beberapa cara yang digunakan untuk menyelesaikan permasalahan perselisihan hubungan industrial, termasuk di dalamnya masalah PHK. Salah satu cara yang dilakukan untuk menyelesaikan permasalahan PHK adalah melalui Pengadilan Hubungan Industrial (PHI).

Di Kota Palembang, jumlah perkara PHK yang diselesaikan melalui Pengadilan Hubungan Industrial sampai saat ini adalah sebanyak 279 perkara (H. Simarmata, komunikasi pribadi. 2020, 6 Oktober). Taslim (komunikasi pribadi. 2020, 6 Oktober) menyatakan bahwa ada beberapa faktor yang melatarbelakangi terjadinya PHK di Kota Palembang, seperti pekerja/ buruh mengundurkan diri secara sukarela atau atas kemauan sendiri, mengundurkan diri atas kemauan sendiri secara tertulis karena berakhirnya kontrak kerja, mengundurkan diri karena sudah memasuki usia pensiun, melakukan kesalahan di perusahaan, perusahaan bangkrut. Dari beberapa faktor tersebut, yang paling dominan terjadi di kota Palembang adalah karena pekerja/buruh dikualifikasikan mengundurkan diri.

Faktor pengunduran diri yang melatarbelakangi terjadinya PHK di kota Palembang dapat dilihat pada beberapa putusan pengadilan (PHI), seperti putusan nomor 157/Pdt.Sus-PHI/2019/PN.Plg, putusan nomor 153/Pdt.Sus-PHI/2019/PN.Plg, putusan nomor 160/Pdt.Sus-PHI/2019/PN.Plg, putusan nomor 159/Pdt.Sus-PHI/2019/PN.Plg, putusan nomor 162/Pdt.SusPHI/2019/PN.Plg, putusan nomor 161/Pdt.Sus-PHI/2019/PN.Plg, putusan nomor 156/Pdt.Sus-PHI/2019/PN.Plg, putusan nomor

\footnotetext{
${ }^{8}$ Kata"empiris" di sini berarti kebenarannya dapat dibuktikan pada alam kenyataan atau dapat dirasakan oleh penca indera. Lihat Depri Libera Sonata. (2014). Metode Penelitian Hukum Normatif dan Empiris: Karakteristik Khas dari Metode Meneliti Hukum. Fiat Justisia Jurnal Ilmu Hukum Volume 9 No. 1 Januari-Maret, hal. 27

${ }^{9}$ Asri Wijayanti dalam Lavenia Nadya Irianti. (2019). Pemutusan Hubungan Kerja Akibat Adanya Perkawinan Antar Pekerja Sekantor Pasca Putusan MK Nomor 13/PUU-XV/2017, JuristDiction Volume 2 No. 1, Januari. hal. 189.

${ }^{10}$ Brankas Everest dalam Sonhaji. (2019). Analisis Yuridis Pemutusan Hubungan Kerja Akibat Kesalahan Berat Pekerja. Adminitrative Law \& Governance Journal, Volume 2 Issue 1, March, hal. 61.

${ }^{11}$ Ibid.

${ }^{12}$ Pasal 1 ayat (2) UU No. 13 Tahun 2003.
} 
Website : http://yustisia.unmermadiun.ac.id/index.php/yustisia

158/Pdt.Sus-PHI/2019/PN.Plg, putusan nomor 154/Pdt.Sus-PHI/2019/PN.Plg, dan putusan nomor 137/Pdt.SusPHI/2019/PN.Plg.

Dari beberapa putusan pengadilan (PHI) kota Palembang tersebut dapat diketahui bahwa faktor yang melatarbelakangi terjadinya PHK di kota Palembang adalah karena pekerja/buruh mengundurkan diri secara sukarela. PHK yang dilakukan oleh Perusahaan tersebut didasarkan pada fakta bahwa Pekerja/buruh tidak mau masuk kerja/mangkir lebih dari (lima) hari kerja secara berturut-turut tanpa keterangan secara tertulis dan pekerja/buruh tidak masuk kerja/mangkir tanpa ada kabar atau tidak memberitahukan tentang ketidakhadiran-nya kepada atasan. Dalam hal ini, perusahaan juga telah memanggil pekerja/ buruh yang tidak masuk kerja/mangkir tersebut sebanyak dua kali secara patut. Tindakan melakukan PHK terhadap pekerja/buruh yang tidak masuk kerja/mangkir selama 5 hari atau lebih secara berturut-turut tanpa kabar merupakan hak perusahaan. ${ }^{13}$

Di lihat dari jenisnya, maka PHK yang dilakukan oleh perusahaan karena pekerja/buruh dikualifikasikan mengundurkan diri termasuk ke dalam jenis PHK atas kehendak perusahaan. PHK jenis ini dikatakan oleh Abdul Khakim paling banyak bermasalah dan menimbulkan perselisihan antara pekerja/buruh dengan pengusaha. Hal ini disebabkan pekerja/buruh jarang ada yang menerima secara sukarela meskipun telah sesuai dengan ketentuan hukum yang berlaku. Salah jenis PHK atas kehendak perusahaan adalah PHK karena pekerja/buruh indisipliner. ${ }^{14}$ Pekerja/buruh yang tidak masuk kerja/mangkir selama 5 (lima) hari atau lebih secara berturut-turut menurut penulis dapat dikategorikan ke dalam PHK karena pekerja/buruh indisipliner atau tidak disiplin atau tidak patuh pada peraturan.

\section{B. Proses Penyelesaian Perkara Pemutusan Hubungan Kerja Di Pengadilan Hubungan Industrial Kota Palembang}

Pada hakikatnya, proses penyelesaian perkara PHK di PHI merupakan upaya penegakan hukum, yaitu suatu proses yang dilakukan untuk menegakkan atau memfungsikan norma-norma hukum secara nyata sebagai pedoman berperilaku dalam lalu lintas atau hubungan-hubungan dalam kehidupan bermasyarakat dan bernegara. ${ }^{15}$ Dengan demikian, proses penyelesaian perkara PHK di Palembang dapat diartikan sebagai proses penegakan norma hukum di bidang hubungan industrial (termasuk PHK) secara nyata di kehidupan masyarakat. Proses ini dilakukan untuk menyelesaikan permasalahan-permasalahan yang terkait dengan perselisihan hubungan industrial (PHK).

Penyelesaian perkara PHK di PHI kota Palembang ini apabila dilihat dari segi subjek (pelaku), maka termasuk dengan penegakan hukum yang oleh subjek dalam arti sempit (terbatas). Dalam hal ini, penegakan hukum itu hanya diartikan sebagai upaya hakim PHI (aparatur penegakan hukum) tertentu untuk menjamin dan memastikan suatu aturan hukum berjalan sebagaimana seharusnya._Kemudian apabila dilihat dari sudut objeknya (segi hukum), maka proses penyelesaian perkara PHK di PHI kota Palembang termasuk ke dalam arti sempit, yaitu penegakan hukum itu hanya menyangkut penegakan peraturan yang formal dan tertulis saja, yaitu UU No 13 Tahun 2003, UU No. 2 Tahun 2004, dan peraturan perusahaan.

UU No. 2 Tahun 2004 telah menegaskan bahwa penyelesaian perkara perselisihan hubungan industrial melalui PHI baru dilakukan apabila tidak ada kesepakatan dalam penyelesaian melalui konsiliasi atau mediasi. ${ }^{16}$ Ketentuan ini kemudian ditegaskan juga dalam putusan MK Nomor 68/PUU-XIII/2015 bahwa perselisihan hubungan industrial (termasuk PHK) wajib dilalukan penyelesaian mediasi atau konsiliasi terlebi dahulu. Di lingkungan peradilan umum, keberadaan PHI sebagai pengadilan khusus ${ }^{17}$ karena hanya berwenang menangani perselisihan hubungan industrial. Salah satu tugas dan wewenang yang dimiliki PHI adalah memeriksa dan memutus perkara mengenai perselisihan PHK di tingkat pertama ${ }^{18}$.

UU No. 2 Tahun 2004 tidak mengatur mengenai tata cara atau proses penyelesaian perkara perselisihan hubungan industrial. Undang-undang tersebut hanya menentukan mengenai hukum acara yang berlaku di PHI adalah hukum acara perdata yang berlaku di Pengadilan dalam lingkungan Peradilan Umum, kecuali yang diatur secara khusus dalam undang-undang ini. ${ }^{19}$ UU No. 2 Tahun 2004 hanya mengatur secara khusus tentang pembebasan biaya bagi pihak-pihak yang berperkara termasuk biaya eksekusi apabila nilai gugatannya di bawah Rp 150. 000.000,00 (seratus lima juta rupiah). ${ }^{20}$ Sesuai ketentuan ini, maka pihakpihak yang berperkara dikenakan biaya apabila nilai gugatannya lebih dari Rp 150.000.000,00.

Dengan demikian, proses penyelesaian perkara PHK di PHI adalah hukum acara perdata yang berlaku di Peradilan Umum, yaitu H.I.R atau Kitab Undang-Undang Hukum Acara Perdata. Penyelesaian perkara di PHI, prosesnya secara umum dimulai dari pengajuan Secara umum proses penyelesaian di PHI mulai dari pengajuan gugatan (pembuatan gugatan, pendaftaran, pembacaan). Dilanjutkan dengan jawaban, replik, duplik, pembuktian (surat, saksi, persangkaan, pengakuan, dan sumpah),

\footnotetext{
${ }^{13}$ Pasal 168 ayat (1) UU No. 13 Tahun 2003 menyatakan, bahwa "Pekerja/buruh yang mangkir selama 5 (lima) hari kerja atau lebih berturut-turut tanpa keterangan secara tertulis yang dilengkapi dengan bukti yang sah dan telah dipanggil oleh pengusaha 2 (dua) kali secara patut dan tertulis dapat diputus hubungan kerjanya karena dikualifikasikan mengundurkan diri."

${ }^{14}$ Abdul Khakim dalam Lavenia Nadya Irianti, op.cit, hal. 199.

${ }^{15}$ Jimly Asshiddiqie, Penegakan Hukum, Terdapat dalam http://www.jimly.com/makalah/namafile/56/Penegakan_Hukum.pdf, (askses 7 Desember 2019).

${ }^{16}$ Pasal 5 UU No 2 Tahun 2004.

${ }^{17}$ Pasal 55 UU No. 2 Tahun 2004.

${ }^{18}$ Pasal 56 huruc c UU No. 2 Tahun 2004.

${ }^{19}$ Pasal 57 UU No. 2 Tahun 2004.

${ }^{20}$ Pasal 59 UU No. 2 Tahun 2004.
} 
kesimpulan/konklusi, putusan perkara, hingga eksekusi (pelaksanaan) putusan. ${ }^{21} \mathrm{Hal}$ ini juga berlaku bagi penyelesaian perkara PHK di Pengadilan Hubungan Industrial Kota Palembang (A. Syarifuddin, Komunikasi Pribadi. 2020, 8 Oktober).

Dari hasil wawancara dengan beberapa hakim, dapat diketahui bahwa proses penyelesaian perkara PHK di PHI kota Palembang dilakukan dengan menjalani persidangan. Adapun tahapan cara atau penyelesaian perkara PHK di PHI Kota Palembang dilakukan dengan cara sebagai berikut:

\section{Pengajuan Gugatan}

Pengajuan gugatan perselisihan hubungan industrial diajukan kepada PHI pada pengadilan negeri Palembang, yang di dalamnya wajib melampirkan risalah penyelesaian melalui mediasi atau konsiliasi. Berkas dikembalikan kepada para pihak yang mengajukan gugatan apabila tidak melampirkan risalah penyelesaian melalui mediasi atau konsiliasi. Gugatan dapat dicabut penggugat sebelum tergugat member jawaban. Proses peradilan berikutnya tidak dilakukan jika gugatan telah dicabut yang dapat disebabkan oleh adanya perdamaian antara tergugat dengan penggugat walaupun gugatan telah dimasukkan ke pengadilan oleh penggugat.

\section{Proses Pemeriksaan}

Dengan adanya gugatan tersebut, maka Pengadilan Negeri Palembang dalam 7 (tujuh) hari kerja menetapkan Majelis Hakim yang terdiri dari 1 (satu) orang hakim sebagai ketua majelis dan 2 (dua) orang hakim adhoc sebagai anggota majelis yang memeriksa dan memutus perselisihan PHK. Dalam proses pemeriksaan perkara PHK pada PHI Kota Palembang dapat dilakukan dengan dua cara yaitu:

a) Pemeriksaan dengan acara biasa

Dalam waktu 7 (tujuh hari) kerja, majelis hakim menetapkan jadwal sidang, pemanggilan saksi atau saksi ahli. Saksi atau saksi ahli wajib memberikan kesaksian dibawah di sumpah dan hakim wajib merahasiakan semua keterangan yang diminta. Sidang pemeriksaan perkara dengan acara biasa dilakukan terbuka untuk umum, kecuali jika mejelis hakim menetapkan lain. Majelis hakim dapat menetapkan hari sidang berikutnya apabila salah satu pihak tidak hadir di persidangan tanpa alasan yang dapat dipertanggungjawabkan.

Pelaksanaan hari sidang berikutnya selambat-lambatnya 7 (tujuh) hari terhitung sejak tanggal penundaan, yang dapat diberikan sebanyak 2 kali. Majelis hakim dapat memeriksa dan memutus perselisihan yang terjadi tanpa dihadiri tergugat, apabila tergugat atau kuasa hukumnya yang sah setelah dipanggil secara patut tidak datang menghadap ke pengadilan pada sidang penundaan terakhir. UU No. 2 Tahun 2004 juga telah menjelaskan bahwa setiap orang yang hadir dalam persidangan wajib menghormati persidangan.

b) Pemeriksaan dengan acara cepat.

Alasan dilakukannya pemeriksaan dengan acara cepat karena terdapat kepentingan para pihak dan atau salah satu pihak yang cukup mendesak yang harus dapat disimpulkan dari alasan-alasan permohonan dari yang berkepentingan. Dalam hal demikian, maka para pihak atau salah satu pihak dapat memohon kepada pengadilan hubungan industrial supaya pemeriksaan sengketa dipercepat.

Setelah diajukan permohonan, maka ketua pengadilan negeri mengeluarkan penetapan tentang dikabulkan atau tidak dikabulkannya permohonan tersebut selama 7 (tujuh) hari kerja setelah diterimanya permohonan terhadap penetapan pemeriksaan dengan acara pemeriksaan cepat tidak digunakan upaya hukum. Apabila dikabulkan, maka ketuga pengadilan negeri dalam jangka waktu 7 (tujuh) hari kerja, mengeluarkan penetapan mengenai majelis hakim yang memeriksa perkara cepat, hari, tempat, dan waktu sidang tanpa melalui proses pemeriksaan biasa. Tenggang waktu yang dimiliki oleh para pihak untuk menyampaikan jawaban dan pembuktian, yaitu tidak lebih dari 14 (empat belas) hari kerja.

Seperti proses pemeriksaan perkara lainnya, dalam proses penyelesaian perkara PHK di PHI kota Palembang juga ada putusannya. Terkait hal itu, di PHI kota Palembang juga dikenal dua jenis putusan, yaitu:

\section{Putusan Sela}

Putusan ini dijatuhkan oleh hakim apabila dalam persidangan pertama secara nyata-nyata pihak pengusaha terbukti tidak melaksanakan kewajibannya membayar upah dan hak-hak yang biasa diterima oleh pekerja/buruh. Putusan sela ini berupa perintah kepada pengusaha untuk melaksanakan kewajibannya kepada pekerja/buruh.

Putusan sela dapat dijatuhkan pada saat hari persidangan itu juga atau pada hari persidangan kedua. Selama pemeriksaan perkara PHK berlangsung dan putusan sela itu tidak juga dilaksanakan oleh pengusaha, maka hakim ketua sidang memerintahkan agar dilakukan sita jaminan yang dituangkan dalam penetapan PHI. Putusan sela dan penetapan PHI tidak dapat diajukan perlawanan dan/atau tidak dapat digunakan upaya hukum.

\footnotetext{
${ }^{21}$ Bandingkan dengan Suherman Toha. (2010). Laporan Akhir Penelitian Hukum Tentang Penyelesaian Hubungan Industrial. Badan Pembinaan Hukum Nasional Kementerian Hukum dan HAM RI, hal.71.
} 


\section{Putusan Akhir}

Putusan ini dilakukan oleh hakim dalam perkara PHK harus didasarkan pertimbangan hukum, perjanjian kerja yang ada, kebiasaan, dan keadilan. Majelis hakim diwajibkan untuk menyelesaikan perkara PHK selambat-lambatnya 50 (lima puluh) hari kerja sejak sidang pertama. Putusan PHI mengenai perselisihan PHK dapat diajukan kasasi ke Mahkamah Agung dalam waktu 14 (empat belas) hari kerja. Putusan PHI ditandatangani oleh hakim, Hakim Ad. Hoc dan panitera pengganti. Panitera pengganti PHI menyampaikan pemberitahuan putusan kepada pihak yang tidak hadir dalam sidang.

Dengan demikian, dapat dipahami bahwa terdapat dua cara yang dapat digunakan oleh PHI kota Palembang untuk menyelesaikan perkara perselisihan hubungan industrial, termasuk PHK. Kedua cara tersebut adalah proses penyelesaian perkara PHK dengan acara cepat dan proses penyelesaian PHK dengan acara biasa. Di PHI Kota Palembang, acara yang sering digunakan untuk menyelesaikan perkara PHK adalah pemeriksaan dengan acara biasa (A. Triawan, Komunikasi Pribadi. 2020, 9 Oktober).

\section{Kendala yang Dihadapi oleh Hakim Pengadilan Hubungan Industrial Kota Palembang dalam Menyelesaikan Perkara Pemutusan Hubungan Kerja}

Proses penyelesaian perkara PHK di PHI kota Palembang tidak berjalan sebagaimana mestinya. Pada pelaksanaannya, masih ada kendala yang dihadapi oleh hakim sehingga dapat menghambat proses penyelesaian perkara PHK di PHI kota pelambang. Sesuai dengan hasil wawancara dengan beberapa hakim PHI kota Palembang, kendala yang dihadapi hakim ketika menyelesaikan perkara PHK adalah tidak adanya kesepakatan diantara para pihak mengenai uang pesangon. Para pihak (pengusaha dan pekerja/buruh) menentukan jumlah uang pesangon masing-masing. Hal ini membuat hakim kerepotan ketika menentukan uang pesangon yang harus dibayarkan oleh pengusaha kepada pekerja/buruh.

Pengaturan mengenai uang pesangon dicantumkan dalam Pasal 156 ayat (1) dan ayat (2) UU No. 13 Tahun 2003. Ketentuan ini menyatakan bahwa uang pesangon merupakan salah satu hak yang wajib diberikan oleh perusahaan kepada pekerja/buruh yang telah di PHK. Perhitungan uang pesangon yang harus dibayarkan kepada pekerja/buruh didasarkan pada masa kerjanya. Pada tataran praktis, ternyata penetapan uang pesangon ini tidak ada kesepakatan antara pekerja/buruh ketika masalah PHK diselesaikan melalui PHI. Hal ini merupakan kendala yang dihadapi oleh Hakim PHI Kota Palembang dalam menyelesaikan perkara PHK.

Kendala tersebut apabila dihubungkan dengan faktor-faktor yang turut menentukan keberhasilan penegakan hukum (penyelesaian perkara PHK di PHI) dapat disebut sebagai faktor kebudayaan ${ }^{22}$. Kebudayaan dalam hal ini merupakan suatu garis pokok tentang perikelakuan masyarakat yang menetapkan peraturan mengenai apa yang harus dilakukan dan apa yang dilarang terkait dengan PHK dan penyelesaiannya melalui PHI. Kebudayaan ini turut menentukan keberhasilan dalam proses penyelesaian perkara PHK di PHI apabila para pihak bersikap lapang dada dalam setiap hasil putusan yang diberikan.

\section{IV.KESIMPULAN DAN SARAN}

\section{A. Kesimpulan}

Berdasarkan pada hasil penelitian dan pembahasan yang diuraikan di atas, maka dapat penulis simpulkan hal-hal sebagai berikut:

1. Terjadinya kasus PHK di kota Palembang disebabkan oleh beberapa faktor, seperti pekerja/ buruh mengundurkan diri secara sukarela atau atas kemauan sendiri, mengundurkan diri atas kemauan sendiri secara tertulis karena berakhirnya kontrak kerja, mengundurkan diri karena sudah memasuki usia pensiun, melakukan kesalahan di perusahaan, perusahaan bangkrut. Dari beberapa faktor tersebut, yang paling dominan sebagai faktor terjadinya PHK di kota Palembang adalah PHK/buruh dikualifikasikan karena mengundurkan diri.

2. Proses penyelesaian perkara PHK di PHI kota Palembang berpedoman pada hukum acara pidana yang berlaku di peradilan umum kecuali mengenai biaya perkara karena telah ditetapkan oleh UU No. 2 Tahun 2004. Proses penyelesaian perkara PHK di PHI kota Palembang dapat dilakukan dengan acara cepat dan acara biasa. Kedua acara itu, yang paling sering digunakan untuk menyelesaikan perkara PHK di PHI Kota Palembang adalah acara biasa.

3. Kendala yang dihadapi oleh Hakim PHI Kota Palembang dalam menyelesaikan perkara PHK adalah para pihak tidak sepakat mengenai uang pesangon. Kendala itu merupakan salah satu faktor yang menghambat proses penegakan hukum, yang disebut faktor kebudayaan.

\section{B. Saran}

Penulis menyarankan agar para pihak yang berperkara bersikap kooperatif, tidak mementingkan ego masing-masing terkait dengan uang pesangon sehingga proses penyelesaian perkara PHK di PHI dapat berjalan lancar sebagaimana mestinya. Di samping, hakim PHI juga perlu bersikap tegas ketika para pihak tidak ada kesepakatan mengenai uang pesangon.

\footnotetext{
${ }^{22}$ Soerjono Soekanto, 2004, Faktor-Faktor yang Mempengaruhi Penegakan Hukum, RajaGrafindo Persada, Jakarta, hlm. hal.42.
} 
Website : http://yustisia.unmermadiun.ac.id/index.php/yustisia

\section{DAFTAR PUSTAKA}

\section{A. Buku}

Soekanto, S, 2004, Faktor-Faktor yang Mempengaruhi Penegakan Hukum. RajaGrafindo Persada, Jakarta.

\section{B. Jurnal}

Asshiddiqie, J. Penegakan Hukum, Terdapat dalam http://www.jimly.com/makalah/namafile/56/Penegakan_Hukum.pdf, (akses 7 Desember 2019). Dahlia \& A. J. (2011). Penyelesaian Perselisihan Hubungan Industrial Berdasarkan UU No. UU Tahun 2004. Wacana Hukum, Vol. IX No. 2, Oktober.

Irianti, L. N. (201). Pemutusan Hubungan Kerja Akibat Adanya Perkawinan Antar Pekerja Sekantor Pasca Putusan MK Nomor 13/PUU-XV/2017. JuristDiction Volume 2 No. 1, Januari 2019.

Sonhaji. (2019). Analisis Yuridis Pemutusan Hubungan Kerja Akibat Kesalahan Berat Pekerja. Adminitrative Law \& Governance Journal, Volume 2 Issue 1, March.

Sonata, D.L. (2019). Metode Penelitian Hukum Normatif dan Empiris: Karakteristik Khas dari Metode Meneliti Hukum. Fiat Justisia Jurnal Ilmu Hukum Volume 9 No. 1 Januari-Maret.

Toha, S. (2010). Laporan Akhir Penelitian Hukum Tentang Penyelesaian Hubungan Industrial. Badan Pembinaan Hukum Nasional Kementerian Hukum dan HAM RI.

\section{Peraturan Perundang-undangan}

Undang-Undang Nomor 13 Tahun 2003 tentang Kenegakerjaan.

Undang-Undang Nomor 2 Tahun 2004 tentang Penyelesaian Perselisihan Hubungan Industrial.

D. Website

Daftar Perkara Pengadilan Hubungan Industrial Kota Palembang, Terdapat dalam http://sipp.pn-palembang.go.id/list_perkara, (akses 5 Desember 2019).

Dewi Aminatuz Zuhriah, D.A. Ketika Momok PHK Mengintai Dunia Ketenagakerjaan Indonesia. Terdapat dalam https://ekonomi.bisnis.com/read/20191209/12/1179407/ketika-momok-phk-mengintai-dunia-ketenagakerjaan-indonesia, (akses 4 Desember 2019).

CNN Indonesia, May Day, Pekerja Ajukan Tujuh Tuntutan Ke Pemerintah. Terdapat dalam https://www.cnnindonesia.com/ekonomi/20190430145434-92390870/may-day-pekerja-ajukan-tujuh-tuntutan-ke-pemerintah, (akses 5 Desember 2019). 